\title{
Trunk muscle function and pelvic alignment associated with the presence of pain in higher education students: a cross-sectional study
}

\author{
Função muscular do tronco e do alinhamento pélvico \\ associados à presença de dor em estudantes do \\ ensino superior: um estudo transversal
}

\author{
Márcio Antônio dos Santos $\mathbb{D}^{\mathrm{D}}$, Carlos Eduardo Viana Santos $\mathbb{D}$, Adriano Rodrigues $\mathbb{D}^{\mathrm{D}}$, Luciana Crepaldi \\ Lunkes
}

Centro Universitário de Lavras (UNILAVRAS), Lavras, MG, Brazil

\begin{abstract}
Introduction: The protective role of muscles in the passive structures of the spine means that their stability and consequent maintenance are associated with pain, especially in the region of the lumbo-pelvic-hip complex. Objective: To determine the prevalence of pain and its association with muscle deficits in higher education students. Method: Descriptive, observational, cross-sectional study that evaluated 120 university students through questionnaires (sample characterization, Nordic musculoskeletal symptoms, pain visual analogue scale and international physical activity). Trunk muscle strength and bridge tests with unilateral knee extension (pelvic alignment) were performed. Results: A high prevalence of pain was found in the lower back (58.41\%). There was no association between the presence of pain, muscle strength and pelvic
\end{abstract}

\footnotetext{
*MAS: undergrad, e-mail: marciocruzeiro15@hotmail.com

CEVS: undergrad, e-mail: carlos.viana.96@outlook.com

AR: PhD, e-mail: adrianorodrigues@unilavras.edu.br

LCL: PhD, e-mail: lucianaclunkes@gmail.com
} 
alignment ( $p>0.05)$. There was an association between the trunk extension and pelvic tilt tests $(p=0.009)$. Conclusion: A high prevalence of low back pain, poor performance in the trunk muscle endurance tests and mild and moderate pelvic misalignment were identified. There was no association between pain, trunk muscle weakness and pelvic misalignment. There was an association between pelvic misalignment and trunk extensor muscle weakness.

Keywords: Pain. Stabilization. Pelvis. Abdomen.

\section{Resumo}

Introdução: A atribuição de um papel protetor da musculatura sobre as estruturas passivas da coluna vertebral faz com que sua estabilização e consequente manutenção tornem-se aspectos associados a dor, principalmente na região do complexo lombo-pélvico-quadril. Objetivo: Verificar a prevalência de dor e a associação da sua presença a déficits musculares em estudantes do ensino superior. Método: Estudo descritivo, observacional e transversal que avaliou 120 universitários através de questionários (caracterização da amostra, nórdico de sintomas osteomusculares, escala visual analógica de dor e internacional de atividade física). Foram executadas provas de resistência muscular do tronco (força muscular) e ponte com extensão unilateral dojoelho (alinhamento pélvico). Resultados: Foi encontrada alta prevalência de dor na região lombar (58,41\%). Não houve associação entre a presença de dor, força muscular e alinhamento pélvico $(p>0,05)$. Houve associação entre o teste de extensão de tronco e inclinação pélvica $(p=0,009)$. Conclusão: Foi identificada uma alta prevalência de dor lombar, baixo desempenho nas provas de resistência dos músculos do tronco e níveis de desalinhamento pélvico leve e moderado. Não houve associação entre as variáveis dor, fraqueza muscular do tronco e desalinhamento pélvico. Houve associação entre o desalinhamento pélvico e a fraqueza dos músculos extensores do tronco.

Palavras-chave: Dor. Estabilização. Pelve. Abdome.

\section{Introduction}

Musculoskeletal pain is highly prevalent in healthy adolescents and young adults, including university students and primarily women, and can persist until the onset of their professional career [1-4]. In general, there is still considerable uncertainty regarding the causal factors of these conditions, where the appearance, persistence and exacerbation of pain may be related to various physical factors, such as repetitive movements and postures [3]. In addition, there is no consensus about protective factors, such as regular exercise, since some studies found no significant association between this variable and pain outcome $[3,4]$. However, the results of most studies reinforce the need for earlier preventive interventions. This is due to an important association between chronic pain and higher disability indices.

Posture is defined as a balancing of body structures determined by the positioning of segments. Due to the transmission of forces from one segment to another, posture may be influenced by the movement of non-adjacent joints, thereby altering certain movement patterns [5]. These changes may be associated with altered muscle activation patterns, involving mechanical and tissue relationships [6]. The current discussion about posture is frequently related to patients, clinics, the media and society as a whole. Despite the absence of convincing evidence to support the general belief that these pains are caused by incorrect posture, a number of interventions and products, including those suggested by health professionals, have been associated with improved or corrected posture aimed at preventing pain [7].

Muscles play an important protective role in the passive structures of the spine. Hypotonicity from disuse is associated with remaining in a particular position for a prolonged period of time, and may result in excessive load transfer, causing pain [8]. In this respect, trunk muscle components influence 
body stabilization [9], acting as primary motors or antagonists of movement and playing a crucial role in body functioning. Their stability provides dynamic and efficient postural control, creating balance around the hip complex [10] and promoting a stable base for the limb muscles [11]. However, several authors have discussed the real influence of transverse abdominal and multifidus muscle activation in situations of chronic pain $[12,13]$.

Central stability is related to trunk muscle movements over the pelvis as a response to internal or external disturbances [14]. The literature reports that poor pelvic alignment may cause changes in the lumbar spine based on the relationship between pelvic tilt or translation and lumbar lordosis [15], given that spine curvature is influenced by the sacral position [16]. In this respect, there are several tests that help assess trunk and pelvic stability and may provide a clear picture of the patient's muscle performance in daily activities, such as isometric strength tests of lumbar spine stabilizers and bridge muscles with unilateral knee extension $[17,18]$. Given the lack of consensus in the literature, the aim of this study was to determine the prevalence of pain and its association with muscle deficits in higher education students.

\section{Method}

Aimed at a more accurate and complete presentation, the subdivision and description of the topics to follow were based on the Strengthening the Reporting of Observational Studies in Epidemiology (STROBE) checklist items [19,20].

\section{Study design}

This is a cross-sectional, observational, descriptive typological study of a well-defined population, where all that was observed was measured a single time via individually collected data.

\section{Ethical criteria}

The methodological study procedures were approved by the Research EthicsCommittee of the Lavras University Center (CAAE 49975615.1.0000.5116), in compliance with the guidelines contained in National Health Council resolution 466/12.
Facilities and participants

Considering a population of 2000 enrolled students, a representative sample was calculated at a $90 \%$ confidence level and $8 \%$ maximum margin of error, totaling a minimum of 100 individuals. However, considering possible exclusions according to the eligibility criteria (15\%) and seeking to guarantee confidence levels without unnecessary sampling, a total of 120 volunteers were included. The inclusion criteria were age greater than or equal to 18 years, from both sexes, enrolled at the Lavras University Center (Unilavras), with no musculoskeletal problems. None of the initially included individuals were excluded. All the data collection procedures were conducted at the Unilavras Physiotherapy Clinic between April and June 2017, after acceptance of the volunteers following an intense recruiting campaign carried out by the principal researcher, who divulged the study throughout the university and invited interested students to take part at a pre-established date and time. All the measures were carried out by the same assessor, familiar with the tests and trained to execute the techniques. To that end, a study pilot was performed to assess 5 randomly selected volunteers not included in the final sample.

\section{Variables and data measurement}

The individuals were assessed individually via anamnesis and Nordic questionnaires on osteomuscular symptoms [21]. Anthropometric variables were collected and body mass index (BMI) calculated. Pain was quantified using the visual analog scale [22]. The international physical activity questionnaire (IPAQ - Short Form) [23] was also used. The pelvic tilt test was performed (bridge test with unilateral knee extension) [18,24] and trunk muscle function evaluated using isometric extension, anterior and lateral flexion [17].

The pelvic alignment test (fair to moderate intraexaminer and substantial interexaminer reliability) was conducted by placing spherical markers on the anterior superior iliac spine (ASIS) of the volunteers $[18,24]$, positioned in dorsal decubitus, hands on the head, hip and knees flexed and feet on the gurney, and instructed to raise their pelvis to the same height as the contralateral limb and hold the position for 10 seconds. The researchers remained behind the subject, observing the height 
of the pelvis, judging the adequate pelvis alignment after observing if the ASIS remained in a straight line parallel to the gurney in the transverse plane.

An image was recorded after 10 seconds in the sustained position with the camera placed on a tripod $80 \mathrm{~cm}$ from the end of the gurney. ImageJ software was used [25] for two-dimensional analysis of the image, which enabled a clear view of the limits of the structures to be measured, reducing the margin of error caused by direct measurement with rigid instruments [26].

Where misalignment was observed, the amount of pelvic drop was measured considering ASIS displacement from the side assessed in relation to the contralateral side. To evaluate this displacement, the angle created between the straight line formed by the two reflexive markers and a horizontal line was measured. The volunteers were classified as follows: no drop (no pelvic drop); slight drop (between zero and one-third of the amplitude); moderate drop (between one and two-thirds of the amplitude); and sharp drop (between two thirds and the highest angle obtained).

All the tests used to assess trunk muscle function $[17,27]$ showed excellent interexaminer reliability and good to excellent intraexaminer reliability [28]. In the extension resistance test, the volunteer was placed in ventral decubitus, with the upper body outside the gurney and the upper edge of the iliac crest supported (Figure 1A). The lower body was secured to the gurney with straps placed across the ankle joint, just above the knee and the pelvis. During the test, individuals remained with their arms crossed over their chest and hands on the contralateral shoulder and could support themselves before and at the end of the test. Time was measured in seconds from the moment the subjects assumed the horizontal position until they were no longer able to maintain it, with a minimum of 101 seconds considered acceptable [27].

For the flexion resistance test, volunteers remained seated, with the upper body leaning on a support with a $60^{\circ}$ inclination (wedge cushion), keeping their trunk aligned, with knees and hips flexed at $90^{\circ}$ and feet stationary. The subjects were instructed to maintain their arms crossed over their chest and hold the position while the support was moved $10 \mathrm{~cm}$ away to initiate the test (Figure 1B). When the subjects leaned against the support once again, the test was considered finished. The minimum acceptable time considered to execute the test was 156 seconds [27].

For lateral resistance, the individuals remained in lateral decubitus with lower limbs extended and instructed to keep their body straight and raise their hips, supported by their feet and forearm. The contralateral hand was supported on the shoulder (Figure 1C). The test was considered finished when the subjects were unable to keep their body aligned, with 58 seconds considered the minimum acceptable time [27].

Percentages were used to classify the quality of trunk muscle function, where test results of $<25 \%$ of the acceptable minimum were characterized as weak resistance; $25-49 \%$ fair resistance; $50-74 \%$ good resistance; e $>75 \%$ excellent resistance.

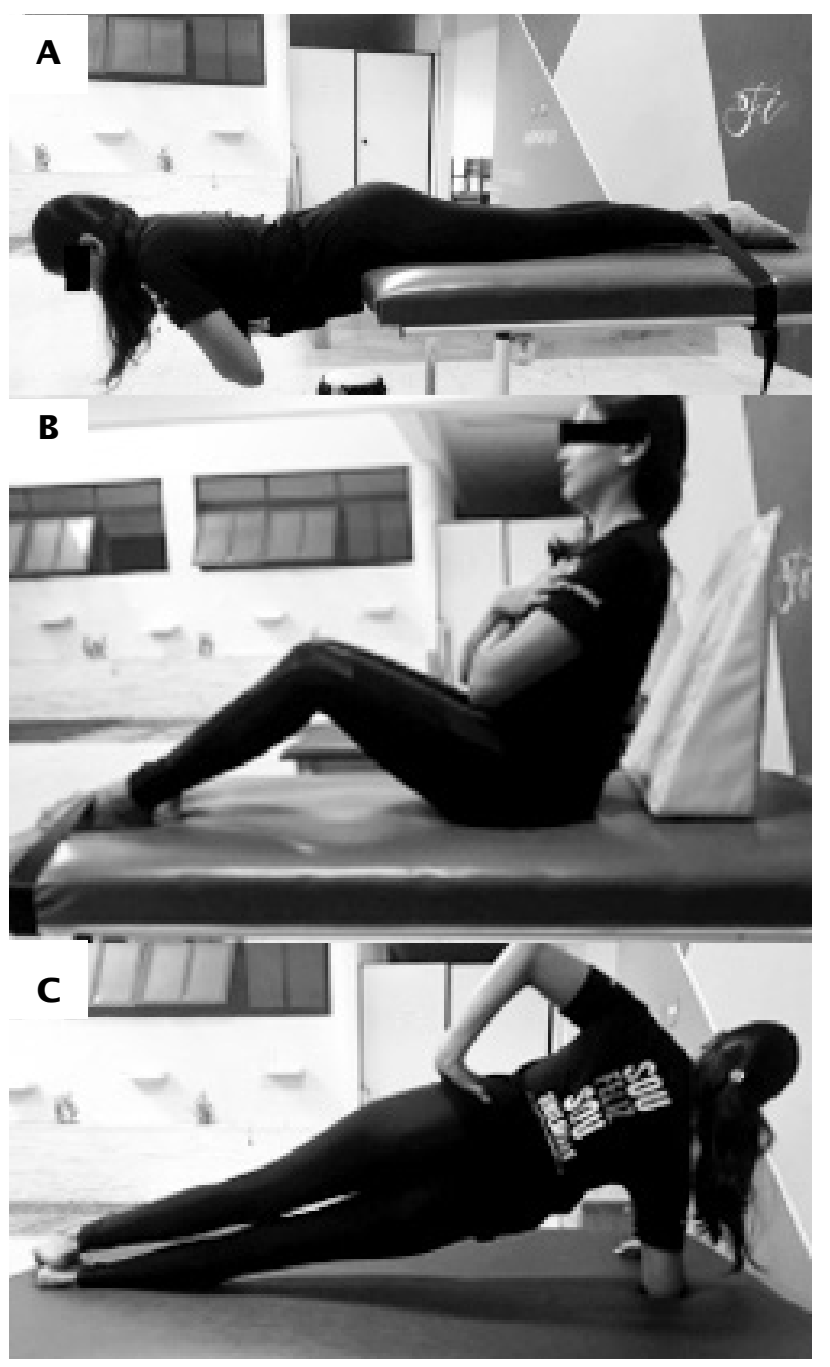

Figure 1 - Tests used to assess trunk muscle function. A: extension resistance test; $\mathrm{B}$ : flexion resistance test; C: lateral resistance test. 
Statistical analysis

The results of the trunk muscle strength test (extension, flexion and right and left lateral plank) were expressed as mean and standard deviation. Data normality was checked by the Kolmogorov-Smirnov and Shapiro-Wilk tests. For the pelvic alignment test (bridge with unilateral knee extension), categorical data (no falls, minor fall, moderate fall and serious fall) were expressed as frequency. Statistical analysis was conducted with the Action ${ }^{\circledR}$ supplement, using the chi-squared test to determine possible associations between the presence of pain, trunk muscle strength and pelvic alignment. All the tests were conducted at a $5 \%$ significance level.

\section{Results}

A total of 120 volunteers were assessed. The sample characteristics show homogeneity between the sexes, with a slight predominance in the men $(51.7 \%)$. Of these, most were single (95.8\%), with income between 2 and 6 minimum monthly wages ( $54.2 \%)$, non-smokers $(86.7 \%)$, with the presence of pain in some part of the body $(84.2 \%)$. Physical activity was similar for both sexes, where most volunteers $(36.7 \%)$ were inactive.

The areas where pain was observed during data collection are listed below. The lumbar region was the most frequently reported. Next, mean self-reported pain levels of the most affected region were measured using the visual analog scale (pVAS), as shown in Table 1.
Table 1 - Sample distribution $(n=101)$ according to pain location, assessed using the Nordic scale of osteomuscular symptoms, and the mean of the most affected region, according to pain level calculated by the pain visual analog scale (pVAS)

\begin{tabular}{cll}
\hline Pain location & $\mathbf{n}$ & $\mathbf{\%}$ \\
\hline Lumbar & 59 & $58.41 \%$ \\
Upper back & 45 & $44.50 \%$ \\
Neck & 36 & $35.60 \%$ \\
Shoulder & 35 & $34.65 \%$ \\
Knee & 28 & $27.72 \%$ \\
Hip/ Thigh & 19 & $18.81 \%$ \\
Wrist/ Hand & 13 & $12.87 \%$ \\
Ankle/ Foot & 12 & $11.88 \%$ \\
Elbow & 1 & $0.99 \%$ \\
\hline Affected region & $\mathbf{n}$ & Mean (pVAS) \pm SD** \\
\hline Lumbar & 39 & $4.53 \pm 2.36$ \\
Upper back & 15 & $4.75 \pm 2.33$ \\
Neck & 10 & $5.03 \pm 1.75$ \\
Knee & 10 & $5.03 \pm 1.52$ \\
Shoulder & 08 & $4.50 \pm 2.04$ \\
Hip/ Thigh & 08 & $4.15 \pm 2.66$ \\
Wrist/ Hand & 06 & $5.03 \pm 1.63$ \\
Ankle/ Foot & 04 & $5.30 \pm 1.11$ \\
Ankle & $01 *$ & 4.30 \\
General & 101 & $4.69 \pm 2.10$ \\
\hline
\end{tabular}

Note: *No standard deviation could be obtained because only 1 individual reported activity-restrictive elbow pain. ${ }^{*}$ Standard deviation.

There was no statistically significant difference between the pain variables and classification levels of extension ( $\mathrm{p}=0.90)$, trunk flexion ( $\mathrm{p}=0.507)$, and right $(\mathrm{p}=0.075)$ and left lateral plank $(\mathrm{p}=0.096)$ test, as demonstrated in Table 2.

Table 2 - Association between the presence or absence of pain and the results of trunk muscle strength tests (trunk extension, trunk flexion, right and left lateral plank) according to the chi-squared test

\begin{tabular}{|c|c|c|c|c|c|}
\hline \multirow{2}{*}{ Pain } & \multicolumn{4}{|c|}{ Trunk Extension } & \multirow[b]{2}{*}{$p$-value } \\
\hline & Weak & Fair & Good & Excellent & \\
\hline No & $52.6 \%(10)$ & $31.6 \%(6)$ & $10.5 \%(2)$ & $5.3 \%(1)$ & \multirow{2}{*}{0.90 (NS) } \\
\hline \multirow[t]{3}{*}{ Yes } & $67.3 \%(68)$ & $26.7 \%(27)$ & $5.9 \%(6)$ & $0.0 \%(0)$ & \\
\hline & \multicolumn{4}{|c|}{ Trunk Flexion } & \\
\hline & Weak & Fair & Good & Excellent & \\
\hline No & $15.8 \%(3)$ & $26.3 \%(5)$ & $15.8 \%(3)$ & $42.1 \%(8)$ & \multirow{2}{*}{0.507 (NS) } \\
\hline \multirow[t]{3}{*}{ Yes } & $22.8 \%(23)$ & $37.6 \%(38)$ & $12.9 \%(13)$ & $26.7 \%(27)$ & \\
\hline & \multicolumn{4}{|c|}{ Plank (right) } & \\
\hline & Weak & Fair & Good & Excellent & \\
\hline No & $52.6 \%(10)$ & $26.3 \%(5)$ & $21.1 \%(4)$ & $0.0 \%(0)$ & \multirow{2}{*}{0.075 (NS) } \\
\hline \multirow[t]{3}{*}{ Yes } & $77.2 \%(78)$ & $15.8 \%(16)$ & $5.9 \%(6)$ & $1.0 \%(1)$ & \\
\hline & \multicolumn{4}{|c|}{ Plank (left) } & \\
\hline & Weak & Fair & Good & Excellent & \\
\hline No & $57.9 \%(11)$ & $31.6 \%(6)$ & $5.3 \%(1)$ & $5.3 \%(1)$ & \multirow{2}{*}{0.096 (NS) } \\
\hline Yes & $80,2 \%(81)$ & $12,9 \%(13)$ & $5,9 \%(6)$ & $1,0 \%(1)$ & \\
\hline
\end{tabular}

Note: ${ }^{\star} N S=$ Non-significant at a $5 \%$ significance level. 
There was an association between pelvic alignment and classification level in the extension test $(p=0.009)$. There was no significant difference between pelvic alignment and classification levels in the trunk flexion $(\mathrm{p}=0.672)$, right $(\mathrm{p}=0.189)$ and left plank tests $(\mathrm{p}=$ 0.115 ), as shown in Table 3. As demonstrated in Table 4, there was no relationship between pelvic misalignment and pain ( $\mathrm{p}=0.276)$.

Table 3 - Association between the results of the pelvic alignment test (bridge with unilateral knee extension) and trunk muscle test results (trunk extension, trunk flexion, right and left plank test) conducted using the chi-squared test

\begin{tabular}{|c|c|c|c|c|c|}
\hline \multirow{2}{*}{$\begin{array}{c}\text { Pelvic } \\
\text { misalignment }\end{array}$} & \multicolumn{5}{|c|}{ Trunk Extension } \\
\hline & Weak & Fair & Good & Excellent & $\mathrm{p}$-value \\
\hline No falls & $0.8 \%(1)$ & $1.7 \%(2)$ & $0.0 \%(0)$ & $0.0 \%(0)$ & \multirow{4}{*}{$0.009 *$} \\
\hline Minor fall & $19.2 \%(23)$ & $15.8 \%(19)$ & $5.8 \%(7)$ & $0.8 \%(1)$ & \\
\hline Moderate fall & $40.0 \%(48)$ & $8.3 \%(10)$ & $0.0 \%(0)$ & $0.0 \%(0)$ & \\
\hline \multirow[t]{3}{*}{ Serious fall } & $5.0 \%(6)$ & $1.7 \%(2)$ & $0.8 \%(1)$ & $0.0 \%(0)$ & \\
\hline & \multicolumn{5}{|c|}{ Trunk Flexion } \\
\hline & Weak & Fair & Good & Excellent & \\
\hline No falls & $0.8 \%(1)$ & $0.0 \%(0)$ & $0.0 \%(0)$ & $1.7 \%(2)$ & \multirow{4}{*}{0.672 (NS) } \\
\hline Minor fall & $6.7 \%(8)$ & $15.8 \%(19)$ & $5.8 \%(7)$ & $13.3 \%(16)$ & \\
\hline Moderate fall & $13.3 \%(16)$ & $16.7 \%(20)$ & $5.8 \%(7)$ & $12.5 \%(15)$ & \\
\hline \multirow[t]{3}{*}{ Serious fall } & $0.8 \%(1)$ & $3.3 \%(4)$ & $1.7 \%(2)$ & $1.7 \%(2)$ & \\
\hline & \multicolumn{5}{|c|}{ Plank (right) } \\
\hline & Weak & Fair & Good & Excellent & \\
\hline No falls & $1.7 \%(2)$ & $0.8 \%(1)$ & $0.0 \%(0)$ & $0.0 \%(0)$ & \multirow{4}{*}{0.189 (NS) } \\
\hline Minor fall & $25.0 \%(30)$ & $11.7 \%(14)$ & $5.0 \%(6)$ & $0.0 \%(0)$ & \\
\hline Moderate fall & $39.2 \%(47)$ & $5.0 \%(6)$ & $3.3 \%(4)$ & $0.8 \%(1)$ & \\
\hline \multirow[t]{3}{*}{ Serious fall } & $7.5 \%(9)$ & $0.0 \%(0)$ & $0.0 \%(0)$ & $0.0 \%(0)$ & \\
\hline & \multicolumn{5}{|c|}{ Plank (left) } \\
\hline & Weak & Fair & Good & Excellent & \\
\hline No falls & $0.8 \%(1)$ & $0.8 \%(1)$ & $0.8 \%(1)$ & $0.0 \%(0)$ & \multirow{4}{*}{0.115 (NS) } \\
\hline Minor fall & $27.5 \%(33)$ & $10.0 \%(12)$ & $3.3 \%(4)$ & $0.8 \%(1)$ & \\
\hline Moderate fall & $41.7 \%(50)$ & $5.0 \%(6)$ & $0.8 \%(1)$ & $0.8 \%(1)$ & \\
\hline Serious fall & $6.7 \%(8)$ & $0.0 \%(0)$ & $0.8 \%(1)$ & $0.0 \%(0)$ & \\
\hline
\end{tabular}

Note: NS $=$ Non-significant at a $5 \%$ significance level.

Table 4 - Association between the results of the pelvic alignment test (bridge with unilateral knee extension) and trunk muscle test results (trunk extension, trunk flexion, right and left plank test) conducted using the chi-squared test

\begin{tabular}{cccc}
\hline \multirow{2}{*}{ Pelvic Misalignment } & \multicolumn{2}{c}{ Pain } & p-value \\
\cline { 2 - 4 } & Absence & Presence & \\
\hline No falls & $0.0 \%(0)$ & $2.5 \%(3)$ & \\
Minor fall & $9.2 \%(11)$ & $32.5 \%(39)$ & 0.276 (NS) \\
Moderate level & $6.7 \%(8)$ & $41.7 \%(50)$ & \\
Serious fall & $0.0 \%(0)$ & $7.5 \%(9)$ & \\
\hline
\end{tabular}

Note: Non-significant at a 5\% significance level.

\section{Discussion}

This study investigated the association between trunk muscle function and the level of pelvic tilt with the presence of pain. One of the components of core stability (center of muscle strength in the trunk region) is the ability of the muscle to generate or resist force [29]. Panjabi [30] reported that lumbar segmental instability is one of the factors associated with a higher incidence of low back pain. However, despite the fact that only $16.6 \%$ of the study sample exhibited good trunk muscle stability and a high index 
of self-reported low back pain (58.4\%), this association between variables was not significant $(p>0.05)$. This reinforces the hypothesis that numerous factors may be associated with the presence or absence of pain, such as sex, age, extreme physical activity levels (sedentary lifestyle or strenuous exercise), smoking and obesity [31-34]. In addition to these factors, psychosocial aspects may also be associated $[35,36]$, including social relationships, self-esteem, mood, social roles, satisfaction with life and independence. Moreover, activation of abdominal bracing may limit movements and increase mechanical stress, providing greater energy expenditure [13,37]. In patients with chronic low back pain, the transverse abdominal muscle seems not to exhibit delayed activation [12], and multifidus activity may be changed, independent of abdominal bracing activation [13].

The main body region responsible for sustaining static and dynamic loads is the lumbar spine, independent of posture [38]. It is important to underscore that the IPAQ questionnaire-short form [23] obtained an average result of seven hours and 30 minutes in the sitting position per day, and earlier findings confirmed that prolonged sitting causes muscle deficiency, provoking fatigue in the anterior muscles of the spine, compromising their stability $[39,40]$. There was no significant difference between the right and left lateral plank test, or in the relationship between pain and pelvic tilt, which may be because the test activates the muscles in general. This was also confirmed in a study that analyzed the behavior of lumbopelvic stabilizer muscles in young people [41].

Trunk flexion exhibited better performance, albeit with no association with pain and pelvic tilt. Most of the sample expressed burning pain in the hip region, suggesting possible dominance of the hip flexors on the abdominals. Confirming this hypothesis, one study reported that when there is abdominal weakness, the psoas muscle displays greater muscle activation, leading to hip instability [42]. Intense abdominals may help lumbopelvic stabilization and decrease the risk of pain, primarily in the lumbar region [43].

There was a significant association between the trunk extension test and pelvic misalignment, indicating a possible association with the weakness of these muscles. However, although a number of earlier studies proved that this factor may be one of the causes of low back pain $[44,45]$, there was no association between pain and trunk muscle weakness $(\mathrm{p}<0.05)$. In addition to the fact that abdominal bracing activation increases thoracic flexion [13], and given that changes in pelvic alignment may potentially alter trunk alignment [46-48], this association can be justified by the near-direct anatomical, kinetic and functional association between the segments involved in trunk extension movement and pelvic control.

Nevertheless, some studies consider that weak abdominal muscles may create disharmony, leading to low back pain [46], suggesting therapeutic pain relief strategies aimed at gaining strength and stability, in addition to improving posture. However, corroborating what was found in the present study, current evidence suggests that isolated exercise or in combination with educational measures, may be more effective in preventing low back pain [47]. For musculoskeletal pain in general, mainly in the thoracic, cervical and lumbar spine, hip, knee and shoulder, good practice recommendations include more patient-centered care [49]. It is important that clinicians investigate the presence of more serious pathologies (red flags) and psychosocial factors, via physical assessment and resorting to imaging examinations only when specifically indicated. The interventions should be aimed at exercise, using a combination of proven manual therapies, providing high-quality conservative treatment, in order to avoid more invasive approaches, such as surgery. Moreover, it is essential to monitor patient progress, providing informative education.

It is known that pain, primarily chronic and debilitating, is increasingly associated with the biopsychosocial model, which includes biophysical, social and psychological dimensions [50]. The findings of the present study contribute to the hypothesis that factors other than mechanical and biological aspects are significantly associated with the presence of pain, such as psychosocial components. Nevertheless, there are numerous gaps in the literature, which hinders the discussion of different aspects, mainly involving multifactorial factors. A study limitation is the fact that we did not assess factors other than mechanical aspects (pelvic alignment and muscle strength), which could help better understand the occurrence of pain in this population. As such, in addition to the factors associated with pain, new studies are needed to investigate the possible increased effect of different therapeutic approaches, thereby helping improve clinical decisions. 


\section{Conclusion}

A high prevalence of low back pain, poor performance in the trunk muscle tests and mild and moderate pelvic misalignment levels were identified. There was no significant association $(\mathrm{p}>0.05)$ between pain, trunk muscle weakness and pelvic misalignment. A significant association $(\mathrm{p}<0.05)$ was found between pelvic misalignment and trunk extensor muscle weakness.

\section{Acknowledgements}

We thank the volunteers from the Lavras University Center (UNILAVRAS) and the Research Support Foundation of Minas Gerais state (FAPEMIG).

\section{References}

1. Zapata AL, Moraes AJP, Leone C, Doria-Filho U, Silva CAA. Pain and musculoskeletal pain syndromes in adolescents. J Adolesc Health. 2006;38(6):769-71.

2. Hanvold TN, Veiersted KB, Wærsted M. A prospective study of neck, shoulder, and upper back pain among technical school students entering working life. J Adolesc Health. 2010;46(5):488-94.

3. Rising DW, Bennett BC, Hursh K, Plesh O. Reports of body pain in a dental student population. J Am Dent Assoc. 2005;136(1):81-6.

4. Smith DR, Leggat PA. Prevalence and distribution of musculoskeletal pain among Australian medical students. J Musculoskelet Pain. 2007;15(4):39-46.

5. Fonseca ST, Ocarino JM, Silva PL, Aquino CF. Integration of stresses and their relationship to the kinetic chain. In: Zachazewski JE, Quillen WS, Magee DJ (Eds.). Scientific foundations and principles of practice in musculoskeletal rehabilitation. St. Louis, MO: Saunders; 2007. p. 476-86.

6. Tateuchi H, Taniguchi M, Mori N, Ichihashi N. Balance of hip and trunk muscle activity is associated with increased anterior pelvic tilt during prone hip extension. J Electromyogr Kinesiol. 2012;22(3):391-7.
7. Slater D, Korakakis V, O'Sullivan P, Nolan D, O'Sullivan K. "Sit up straight": Time to Re-evaluate. J Orthop Sports Phys Ther. 2019;49(8):562-4.

8. Borges LF, Rodrigues RB, Valente PHF, Nogueira MS, Araújo RF, Alves FAVB, et al. Análise postural de alunos de 10 a 12 anos do Colégio Estadual Américo Antunes, em São Luís de Montes Belos/GO. Rev Elet Fac Montes Belos. 2015;8(3):178-9.

9. Carvalho ACA, Lacerda FB, Macêdo MP. Treinamento de estabilização central em atletas de triathlon : Um estudo clínico. Fisioterapia \& Saude Funcional. 2014;3(2):24-30.

10. Cadó T, Ataualpa A, Schuster D, Cabral J, Braz M, Zambarda S, et al. Avaliação da ativação dos músculos do core de acadêmicos do curso de fisioterapia. Rev Contexto Saude. 2013;11(20):737-42.

11. Carlos LC. Análise biomecânica dos músculos do core em praticantes de diferentes modalidades de treinamento [master's thesis]. Rio Claro: Universidade Estadual Paulista; 2016. 65 p.

12. Gubler D, Mannion AF, Schenk P, Gorelick M, Helbling $\mathrm{D}$, Gerber $\mathrm{H}$, et al. Ultrasound tissue doppler imaging reveals no delay in abdominal muscle feed-forward activity during rapid arm movements in patients with chronic low back pain. Spine 2010;35(16):1506-13.

13. Coenen P, Campbell A, Kemp-Smith K, O’Sullivan P, Straker L. Abdominal bracing during lifting alters trunk muscle activity and body kinematics. Appl Ergon. 2017;63:91-8

14. Zazulak BT, Hewett TE, Reeves NP, Goldberg B, Cholewicki J. The effects of core proprioception on knee injury: A prospective biomechanical-epidemiological study. Am J Sports Med. 2007;35(3):368-73.

15. Roussouly P, Pinheiro-Franco JL. Sagittal parameters of the spine: biomechanical approach. Eur Spine J. 2011;20(Suppl 5):578-85.

16. Marty C, Boisaubert B, Descamps H, Montigny J, Hecquet J, Legaye J, et al. The sagittal anatomy of the sacrum among young adults, infants, and spondylolisthesis patients. Eur Spine J. 2002;11(2):119-25.

17. Oliveira VMA, Beltrão NB, Pitangui ACR, Castro AR, Correia Jr MAV, Araújo RC. Avaliação da resistência isométrica dos músculos do tronco em adolescentes de diferentes idades e sexos. Conscientiae Saude. 2015;14(2):236-45. 
18. Andrade JA, Figueiredo LC, Santos TRT, Paula ACV, Bittencourt NFN, Fonseca ST. Confiabilidade da mensuração do alinhamento pélvico no plano transverso durante o teste da ponte com extensão unilateral do joelho. Rev Bras Fisioter. 2012;16(4):268-74.

19. Elm E, Altman DG, Egger M, Pocock SJ, Gøtzsche PC, Vandenbroucke JP. Strengthening the Reporting of Observational Studies in Epidemiology (STROBE) Statement: Guidelines for reporting observational studies. UroToday Inc. 2009;2:806-8.

20. Malta M, Cardoso LO, Bastos FI, Magnanini MMF, Silva CMFP. STROBE initiative: guidelines on reporting observational studies. Rev Saude Publica. 2010;44(3):559-65.

21. Pinheiro FA, Tróccoli BT, Carvalho CV. Validity of the Nordic Muscoloskeletal Questionnaire as morbidity measurement tool. Rev Saude Publica. 2002;36:307-12.

22. Andrade FA, Pereira LV, Sousa FAEF. Mensuração da dor no idoso: Uma revisão. Rev Latino-Am Enfermagem. 2006;14(2):271-6.

23. Matsudo S, Araújo T, Matsudo V, Andrade D, Andrade E, Oliveira LC, et al. Questionário Internacional de Atividade Física (IPAQ): Estudo de validade e reprodutibilidade no Brasil. RBAFS. 2012;6(2):5-18.

24. Santos TRT, Andrade JA, Silva BL, Garcia AFA, Persichini Filho JGW, Ocarino JM, et al. Active control stabilization of pelvic position in the transverse plane: An evaluation of soccer players' performance. Phys Ther Sport. 2014;15(3):189-93.

25. ImageJ n.d. [cited 2020 May 29]. Available from: https:// imagej.nih.gov/ij/.

26. Hochman B, Castilho HT, Ferreira LM. Padronização fotográfica e morfométrica na fotogrametria computadorizada do nariz. Acta Cir Bras. 2002;17(4):258-66.

27. Wilkerson GB, Giles JL, Seibel DK. Prediction of core and lower extremity strains and sprains in collegiate football players: A preliminary study. J Athl Train. 2012;47(3):264-72.

28. Araújo RC, Mendes EM, Ribeiro AC, Pitangui ACR. Confiabilidade das medidas de avaliação de resistência iso-métrica dos músculos do tronco em adolescentes sedentários. Arq Cienc Saude. 2014;21(2):34-43.
29. Leetun DT, Ireland ML, Willson JD, Ballantyne BT, Davis IMC. Core stability measures as risk factors for lower extremity injury in athletes. Med Sci Sports Exerc. 2004;36(6):926-34.

30. Panjabi MM. Clinical spinal instability and low back pain. J Electromyogr Kines. 2003;13(4):371-9.

31. Hoy D, Bain C, Williams G, March L, Brooks P, Blyth F, et al. A systematic review of the global prevalence of low back pain. Arthritis Rheum. 2012;64:2028-37.

32. Heneweer H, Vanhees L, Picavet HSJ. Physical activity and low back pain: A U-shaped relation? Pain 2009;143(1-2):21-5.

33. Heneweer H, Staes F, Aufdemkampe G, van Rijn M, Vanhees L. Physical activity and low back pain: A systematic review of recent literature. Eur Spine J. 2011;20:826-45.

34. Ferreira PH, Beckenkamp P, Maher CG, Hopper JL, Ferreira ML. Nature or nurture in low back pain? Results of a systematic review of studies based on twin samples. Eur J Pain. 2013;17(7):957-71.

35. Kamper SJ, Apeldoorn AT, Chiarotto A, Smeets RJEM, Ostelo RWJG, Guzman J, et al. Multidisciplinary biopsychosocial rehabilitation for chronic low back pain. Cochrane Database Syst Rev. 2014;9:1-164.

36. Ramond A, Bouton C, Richard I, Roquelaure Y, Baufreton C, Legrand E, et al. Psychosocial risk factors for chronic low back pain in primary care: a systematic review. Fam Pract. 2011;28(1):12-21.

37. Campbell A, Kemp-Smith K, O'Sullivan P, Straker L. Abdominal Bracing Increases Ground Reaction Forces and Reduces Knee and Hip Flexion During Landing. J Orthop Sports Phys Ther. 2016;46(4):286-92.

38. Candotti CT, Noll M, Cruz M. Prevalência de dor lombar e os desequilíbrios musculares em manicures. Arq Mov. 2010;6(1):125-40.

39. Freitas KPN, Barros SS, Ângelo RCO, Uchôa EPBL. Lombalgia ocupacional e a postura sentada: efeitos da cinesioterapia laboral. Rev Dor. 2011;12(4)308-13.

40. Silva JN, Cusatis Neto R. Prevalência de dor lombar em pessoas que trabalham na postura sentada. UNILUS Ensino Pesqui. 2016;13(32):67-75. 
41. Melo Filho J, Menossi BRS, Preis C, Bertassoni Neto L, Stabelini Neto A. Análise da musculatura estabilizadora lombopélvica em jovens com e sem dor lombar. Fisioter Mov. 2013;26(3):587-94.

42. Massuda KC, Muzili NA, Lima DF, Taciro C, Oliveira Jr SA, Martinez PF. Incidence of low back pain according to physical activity level in hospital workers. Rev Dor. 2017;18(1):8-11.

43. Mourcel PL. Avaliação da prevalência de dor lombar em jovens adultos e avaliação da resistência dos flexores e extensores do tronco em indivíduos com e sem história de dor lombar não específica [bachelor's thesis]. Porto, Portugal: Universidade Fernando Pessoa; 2017.14 p.

44. Schmit EFD, Brito JD, Nóbrega SR, Araújo-Neto SA, Andrade PR, Ferreira JJDA, et al. Efeitos da fisioterapia na força, atividade mioelétrica e dor, em lombálgicos crônicos. Conscientiae saude. 2016;15(2):183-90.

45. Kiesel KB, Butler RJ, Duckworth A, Halaby T, Lannan K, Phifer C, et al. Experimentally induced pain alters the EMG activity of the lumbar multifidus in asymptomatic subjects. Man Ther. 2012;17(3):236-40.
46. Brandalize $M$, Leite N. Alterações ortopédicas em crianças e adolescentes obesos. Fisioter Mov. 2010;23(2):283-8.

47. Steffens D, Maher CG, Pereira LSM, Stevens ML, Oliveira VC, Chapple M, et al. Prevention of lowback pain a systematic review and meta-Analysis. JAMA Intern. Med. 2016;176(2):199-208.

48. Murta BAJ. Avaliação da influência do alinhamento pélvico sobre a postura de tronco e ombro e sobre a atividade eletromiográfica de rotadores superiores da escápula [dissertarion]. Belo Horizonte: Universidade Federal de Minas Gerais; 2015. 62 p.

49. Lin I, Wiles L, Waller R, Goucke R, Nagree Y, Gibberd M, et al. What does best practice care for musculoskeletal pain look like? Eleven consistent recommendations from high-quality clinical practice guidelines: Systematic review. Br J Sports Med. 2020;54:79-86.

50. Hartvigsen J, Hancock MJ, Kongsted A, Louw Q Ferreira ML, Genevay S, et al. What low back pain is and why we need to pay attention. Lancet. 2018;391(10137):2356-67.

Received: $12 / 02 / 2019$

Recebido: 02/12/2019

Approved: 08/03/2020

Aprovado: 03/08/2020 